Made available courtesy of Alliance for Children and Families: http://alliance1.org/

***Reprinted with permission. No further reproduction is authorized without written permission from the Alliance for Children and Families.

This version of the document is not the version of record. Figures and/or pictures may be missing from this format of the document.***

\title{
Service providers' perception of factors that help or hinder homeless families
}

Lindsey, Elizabeth W

Families in Society; Mar/Apr 1998; 79, 2; ProQuest Research Library

pg. 160

Elizabeth W. Lindsey

\section{ABSTRACT}

Homeless shelter directors in two southern states were surveyed to ascertain their perceptions of factors that help or hinder homeless, mother-headed families in emerging from homelessness. Respondents believed that mothers' attitudes and motivation were the most important factors in getting and keeping housing and that lack of social supports and relationship difficulties were the most significant problems families faced in their attempts to emerge from homelessness. Scarce housing was seen as the most significant barrier within the community. The findings are compared with findings from other studies, and explanations for differing results are presented. The author discusses the implications of the findings for service providers and communities in light of recent welfare-reform legislation.

Elizabeth W. Lindsey is assistant professor, Department of Social Work, University of North Carolina at Greensboro, Greensboro, North Carolina. This article is based on work funded by a New Faculty Grant, University of North Carolina at Greensboro.
$F_{c}^{a}$ Service Providers' Perception Of Factors That Help or Hinder Homeless Families 1980s. In 1985 , the US Conference of Mayors estimated that 25\% of the total homeless population were members of homeless families (Reyes \& Waxman, 1986). By 1989 , this figure had risen to $36 \%$ (Reyes \& Waxman, 1989b). According to the U.S. Department of Housing and Urban Development (1994), families are the fastest growing segment of the homeless population. The vast majority of these families $(80 \%-90 \%)$ are headed by single mothers (Burt \& Cohen, 1989; Reyes \& Waxman, 1989a). With the passage of federal welfare reform legislation, it is possible that family homelessness might increase even more in the future. Families whose benefits terminate before mothers are able to earn an adequate income will be at high risk for becoming homeless.

Although family homelessness has been of increasing concern, little research has been done on the process by which families are able to emerge from homelessness. Instead, research efforts have focused on precipitants of homelessness (Bassuk \& Rosenberg, 1988; McChesney, 1990; Weitzman, Knickman, \& Shinn, 1990), characteristics of homeless family members (Bassuk, 1990; Johnson, 1989; Mills \& Ota, 1989), the effect of homelessness on family members (Hall \& Maza, 1990; Rafferty \& Shinn, 1991; Wright, 1990), and programs that serve homeless families (Hutchison, Searight, \& Stretch, 1986; Phillips, DeChillo, Kronenfeld, \& Middleton-Jeter, 1988). Thus, although a lot is known about how families become homeless, who these families are, and how homelessness affects family members, little is known about how families are able to resolve the issues that led to their homeless condition and to secure permanent housing.

This article addresses this research gap by reporting service providers' perceptions of factors that influence the process by which

Families in Society: The Journal of Contemporary Human Services Copyright 1998 Families International, Inc. 
homeless, mother-headed families are able to secure stable housing. These findings have implications for policy and program development, education and training of service providers, and communities that are concerned about the growing problem of homelessness.

\section{Review of Literature}

One of the few studies to examine factors that influence how families are able to emerge from homelessness was conducted in three California counties (The Stanford Center for the Study of Families, Children and Youth, 1991). Service providers and parents interviewed for this study agreed on the most important factors influencing families' ability to emerge from homelessness: increased income, affordable housing, and social support (specifically, being able to stay with family or friends). In addition, service providers believed that knowing how to use the social service system, being homeless for a brief period, and internal strengths and motivation were also important. In testing the factors that determined what families got out of homelessness, researchers substantiated that families that knew the intricacies of the social service system and how to use it had a better chance to secure housing. Interestingly, personal characteristics were found not to be as crucial to getting out of homelessness. Specifically, the authors report,

The level of substance abuse and mental illness among formerly homeless families were virtually identical to those of the homeless families [and] there seemed to be no greater level of energy, organization, or personal initiative among families who got out of homelessness compared with families who were homeless. (The Stanford Center for the Study of Families, Children and Youth, 1991, p. 36)

The difference between those families that found homes and those that did not find homes was their ability to access resources, particularly housing resources, and the level of social support they received from family and friends. This finding questions the validity of the "bootstrap theory," which holds that planfulness and determination are major factors in families' success in emerging from homelessness, and makes a strong case for increasing resources for homeless families.

Rocha, Johnson, McChesney, and Butterfield (1996) looked at demographic predictors of families' ability to access permanent housing upon leaving two St. Louis shelters throughout a 10 -year period. Only three variables predicted permanent-housing placement: the number of children in the family, race, and the year of shelter stay. Larger families and African American families were less likely to move into permanent housing than were smaller families and White families. In addition, families were five times more likely to find permanent housing in 1983 than in 1992, regardless of demographic predictors, a finding the authors attributed to the development of transitional housing programs in the St. Louis area during that 10 year period. They also noted that the proportion of African American homeless families increased during that time, raising questions about the validity of race as a predictor of housing permanency.
Neither the Stanford study (1991) nor the Rocha and colleagues (1996) study looked at the process by which families are able to secure permanent housing after episodes of homelessness. These two studies also tended to focus on individual and familial characteristics and resources, although both acknowledged the lack of affordable housing in their geographic areas. On the basis of indepth interviews with formerly homeless single mothers, Lindsey (1994-95) conducted a qualitative study that revealed two interrelated dimensions of restabilization. The first dimension, the process of restabilization, had three stages: meeting immediate family needs, creating a new home, and maintaining stability. The second dimension consisted of four major factors that affected the process of restabilization: children, personal resources, external resources, and socioeconomic context.

Each stage in the process of restabilization included several tasks that had to be accomplished if the mother was to be successful in moving through the entire process. To the meet the family's immediate needs stage, mothers had to locate to a temporary shelter. After they were temporarily housed, mothers had to maintain their parental role within the context of shelter life, keep up their own morale, and try to preserve any remaining aspects of stability, such as working, going to school, or keeping their children in school. The second stage in the restabilization process, creating a new bome, included the tasks of managing cash flow to support their children and to save for rent and utility deposits, addressing personal and in- 
terpersonal problems such as substance abuse or ongoing harassment by an abusive partner, and locating and furnishing a new home. The final stage, maintaining family stability, included the tasks of continuing to manage finances, continuing to manage ongoing personal and interpersonal problems that threatened family stability, and reestablishing or reaffirming family relationships that may have been disrupted during the spell of homelessness, particularly the parental role.

The mothers in this study perceived four major factors that affected their ability to emerge from homelessness (Lindsey, 1996). The first factor, presence of their children, was deemed to be important because the children served as a source of motivation for the mothers and were crucial to accessing financial resources through the AFDC program. Some mothers reported that children provided emotional support that helped them maintain their morale. The second factor, personal resources, comprised the mother's coping skills and individual characteristics, such as persistence, determination, and knowledge of social service systems. The third factor, external resources, included two components: formal help received from agencies or organizations and informal help received from family and friends. The fourth factor was the socioeconomic context of the community within which the family lived, specifically, the job and housing markets in the geographic area and racial or sex discrimination experienced by the mothers.

Although formerly homeless parents are a valid and valuable source of information about the process of restabilization, service providers' perspective, which may differ somewhat from that of homeless parents, should be evaluated (The Stanford Center for the Study of Families, Children and Youth, 1991). Several studies have examined the characteristics and attitudes of providers of services to homeless persons. Hagen and Hutchison (1988) found that only $28 \%$ of homeless service providers

${ }^{6 T}$ Thirty-five percent [of service providers interviewed] believed that the community was reluctant to provide too much help for homeless people because of fears that [they] would move into the area to take advantage of services.

in Albany, New York, had formal social work training $(10 \% \mathrm{BSW}$; $18 \% \mathrm{MSW}$ ) and that the average experience working with homeless people was less than two years.

The service providers believed they were most successful in gaining access to income maintenance and mental health services for their clients but were not very successful in gaining access to permanent housing for homeless clients. In another study, Degarmo, Feltey, and Pendleton (1993) found that few providers of services to homeless people had received specific training about how to work with that population. These studies indicate that the education and training of those who work with homeless families may play an important part in understanding how to help families emerge from homelessness.

Dluhy (1990) surveyed 57 managers of programs that served homeless people in three south Florida counties. This work adds to the idea that a cluster of factors, both individual and systemic, contribute to families' ability to get out of homelessness. The managers in this study believed that the primary causes of homelessness were lack of affordable low-cost housing $(26.8 \%)$; individual pathology, including mental illness, substance abuse, "growing up without an intact family or some other illness or condition that prevents normal participation in the work force or community life" (p. 29) (19.6\%); extreme poverty $(14.3 \%)$; and welfare dependency $(3.6 \%)$. Asked about obstacles to change in their communities, $71.9 \%$ of the managers cited a reluctance on the part of highlevel community leaders to deal with the issue, $96 \%$ cited lack of interest within the business community, and $71.9 \%$ indicated an overlap of governmental jurisdictions that allowed all levels of government to assume the problem was being dealt with at another level. Thirty-five percent believed that the community was reluctant to provide too much help for homeless people because of fears that homeless people would move into the area to take advantage of services.

Tracy and Stoecker (1993) explored service providers' perceptions regarding the causes and solutions of homelessness. The cause of homelessness was most frequently attributed to a combination of sys- 
temic and individual factors. However, the majority of respondents cited systemic factors such as lack of affordable housing, the economy, jobs or wages, and governmental policy as primary causes of homelessness. All of the respondents cited systemic rather than individual solutions to the problem. Such solutions included creation of affordable housing, job training and development, "creating public awareness to stimulate involvement" (p. 49), and economic measures such as raising the minimum wage. However, most of the respondents believed that "individual and systemic approaches are complementary and that both are necessary to end homelessness" (p. 51).

Previous studies of homelessness have frequently ignored a large proportion of individuals and families because residents of battered women's shelters have typically not been included in such studies (Steinbock, 1995). Yet, nationally, it is estimated that $46 \%$ (Waxman \& Hinderliter, 1996) to $50 \%$ (Zorza, 1991) of families become homeless because of domestic violence. Poor women and families are most at risk of becoming homeless when they flee abuse (Steinbock, $1995)$, and $33 \%$ to $60 \%$ of women eventually return to their batterers because of lack of affordable housing (National Coalition for the Homeless, 1996). Goodman, Saxe, and Harvey (1991) and Browne (1993) suggested that many battered women suffer from post traumatic stress disorder (PTSD), and Browne noted that "ongoing physical or sexual abuse is listed under the category of extreme stressors on [DSM-III-R] Axis IV classifications" (p. 376). Browne also pointed out that homeless women who have survived abuse must overcome the same systemic barriers as other homeless women, while coping with the additional burden of ongoing effects on their ability to "negotiate effectively in the world and providers' reactions to or lack of understanding of the manifestations of trauma in homeless women and children" (p. 380). The fact that half of homeless families have experienced domestic violence indicates that attention must be paid to this group and its special problems in any study of homeless families.

At this point in the development of ideas about how to solve the complex problems associated with helping homeless mother-headed families to emerge from homelessness, the research is somewhat fragmented. Existing literature focuses primarily on service providers' perceptions of causes of homelessness and on programs or other initiatives that address the problem. Aside from the Stanford study (1991), little research has looked at service providers' perceptions about how families actually emerge from homelessness. The purpose of the present research project was to address this gap by examining service providers' perceptions of factors that help and hinder the process of restabilization among mother-headed homeless families.

\section{Methods}

\section{Design and Instrumentation}

This descriptive exploratory study used a survey design with a nonrandom sample. In September 1994 , surveys were mailed to directors of all 165 homeless shelters that served families in North Car- olina and Georgia, including domestic violence shelters. These two states were selected because the author had already conducted qualitative studies of formerly homeless mothers' perceptions of the process of restabilization in these two states. The decision to use a nonrandom sample was based on two factors: the exploratory nature of the study (the primary purpose was not to test hypotheses but to generate knowledge at a more basic level) and a desire to gather as much information as possible. The relatively small number of shelters that served families in the two states meant that use of a random sample could have reduced the number of respondents significantly. Thus, the decision was made to sample the entire population of familyserving shelters in the two states.

The Total Design Method (Dillman, 1978) was used to conduct the survey, including an introductory postcard alerting directors to the forthcoming survey, a cover letter explaining the purpose of the survey, two follow-up mailings, and subsequent telephone calls. These efforts resulted in an overall response rate of $54 \%(n=89)$.

The survey questionnaire, developed specifically for this project, was based on literature on that focused on how families emerge from homelessness and the perceptions of providers of services to homeless persons, previous research done by the author on homeless mothers' perceptions of the restabilization process, and interviews with three service providers. The four-part questionnaire included items related to personal, social, and structural or systemic factors that have been linked to causes and conse- 
quences of homelessness. Part 1 asked respondents to indicate on a 4-point scale how important various factors are to families' success or difficulty in emerging from homelessness. Part 2 asked respondents to indicate the extent to which specific elements of the local community service structure (housing, employment, financial and concrete assistance, and other services) are barriers or assets to families attempting to emerge from homelessness (5-point Likert scale). Part 3 asked for specific information about the shelters and the populations they served. Part 4 asked for information regarding respondents' position, education, and experience working with homeless populations. The questionnaire was field tested with the three shelter providers who had been interviewed during the survey development phase, and alterations were made before the final survey was mailed.

\section{Data Analysis}

Because this study was exploratory and used a nonrandom sample, descriptive statistics (frequency distributions and measures of central tendency) were used to analyze the data initially.

Responses to individual items in Part 1 were grouped to assess respondents' perceptions about factors that contribute to successful restabilization and factors that make the restabilization process more difficult. The Success Factors scale was created by grouping related items into the following summary indices (alpha levels are indicated for each index): access to housing $(=.06)$, personal attitude and motivation $(=.59)$, social supports $(=.54)$, employment $(=$ $.60)$, education/training $(=.85)$, coping skills $(=.33)$, financial and food assistance $(=.76)$, and access to mental health/substance abuse treatment $(=.79)$. Although some of these reliabilities were low, possibly because of the small number of items on some subscales, the overall reliability for the Success Factors scale was .72. Similarly, the Difficulty Factors scale was developed by grouping related items into the following summary indices: housing $(=.82)$, education/ training $(\mathrm{a}=.81)$, financial and food assistance $(=.91)$, access to mental health or substance abuse treatment $(=.81)$, coping skills $(=$ $.55)$, employment $(=.70)$, social supports $(=.69)$, relationship difficulties $(=.67)$, mental health or substance abuse problems $(=.82)$, and attitude and motivation ( = .53). The overall reliability for the Difficulty Factors scale was .83. Means were computed to assess the importance of each of the summary indices in families' success and difficulties in getting and keeping adequate housing.

In Part 2, a Community Service Structure scale asked respondents to indicate the extent to which various aspects of their local community service structure were barriers or assets to families' attempts to emerge from homelessness. This scale had four subscales or summary indices: housing $(=.80)$, employment $(=.75)$, financial and concrete assistance $(=.86)$, and other services $(=.86)$. The overall reliability for the Community Service Structure scale was .73 .

After the descriptive analyses were completed, $t$-tests were run to determine differences in responses to certain questions according to the type of shelter surveyed (domestic violence or not domestic violence) or the educational background of the respondent (BSW and MSW compared with respondents with no social work degree). Because of the large number of items involved in the analyses and because this was not a random sample, a conservative approach to interpreting the data was adopted. First, the acceptable significance level for the $t$-tests was set at .01 . Second, Hotelling's test of significance was run on each of the scales to assess the likelihood that any significant findings appeared by chance. An F score $\propto .05$ was used as the criterion for accepting the findings from each scale as significant.

\section{Respondent and Shelter Characteristics}

Sixty-two percent of respondents were directors of shelters or of transitional living programs; $21 \%$ were case managers. Respondents had worked at their shelters for an average of 5 years (range 1-22 years). They had worked with homeless families for an average of 12 years (range $3-40$ years). This amount of experience compares favorably with the average of less than two years of experience reported for the Albany study (Hagen \& Hutchison, 1988). However, survey respondents were less likely than the Albany respondents to have had formal social work training with only $13.5 \%$ possessing either a BSW (7.9\%) or an MSW (5.6\%) as compared with a total of $28 \%$ of professionally trained social workers in Albany. Other educational backgrounds included bachelor's degrees (29\%), 
associate degrees (18\%), high school diploma or GED (10\%), and a master's degree in another field $(9 \%)$.

Respondents were asked to characterize the type of shelter they operated. Fifty-two percent provided shelter to victims of domestic violence or sexual assault, $26 \%$ provided both emergency and transitional shelter, $11.4 \%$ were emergency only, and $8 \%$ were transitional only. The shelters tended to be located in counties with midsized populations: $13.5 \%$ of the counties represented had a population of less than $25,000,43 \%$ had a population in the range of $25,000-100,000,27 \%$ were in counties with populations of $100,000-199,000$; and $16.9 \%$ were located in counties with population greater than 199,000 . These shelters served an average of 11 families and 33 individuals per month, with a mean of 7.3 staff members (combined full and part time).

The shelters served a variety of homeless populations. Ninety-six percent served women with children, $37 \%$ served two-parent families with children, $32.6 \%$ served single fathers with children, $22.5 \%$ served couples without children, $80 \%$ served single women, and $29 \%$ served single men. The mean proportion of single, mother-headed families that these shelters served was $84 \%$ (range $20 \%-100 \%$ ), and the mean proportion of single father-headed families was $3 \%$ (range $1 \%-50 \%$ ). Approximately $12 \%$ (range $1 \%-100 \%$ ) of families were headed by two parents. The racial or ethnic breakdown of families served was reported to be $48 \%$ White, not of Hispanic origin; $48 \%$ African American; and 4\% Hispanic.

\section{Findings}

Respondents were asked to indicate the percentage of families in their shelters who became homeless for a variety of reasons. Because $52 \%$ of the shelters were domestic violence shelters, $t$-tests were run to determine whether the cause of homelessness varied by type of shelter. Table 1 indicates mean responses for each shelter type. The only significant difference in responses was that respondents from domestic-violence shelters were more likely to see "leaving an abusive relationship" as a primary cause of homelessness than were respondents from other shelters. Although Hotelling's test indicated this finding could be due to chance, the very low $p$ value $<$ $.00)$ and the fact that these shelters are operated specifically for women who are escaping abuse support this finding as significant. No difference was found in perceptions of causes of homeless according to the educational background of the respondents.

Survey respondents were asked to indicate the proportion of the mothers in their shelters who experienced certain problems. Table 2 presents these findings for all respondents undifferentiated by shelter type or educational background. More than half of respondents indicated that more than $90 \%$ of the mothers they serve have been in abusive relationships, which is congruent with findings of other studies (Browne, 1993;

Goodman, 1991). Other problems, which are reported in Table 2, relate directly to financial difficulties, either as causes or effects: mothers'

\begin{tabular}{|c|c|c|c|c|c|}
\hline \multirow{2}{*}{$\begin{array}{l}\text { Cause } \\
\begin{array}{l}\text { Leaving an abusive } \\
\text { relationship }\end{array}\end{array}$} & \multicolumn{2}{|c|}{$\begin{array}{l}\text { Domestic } \\
\text { Violence } \\
(n=47)\end{array}$} & \multicolumn{2}{|c|}{$\begin{array}{l}\text { All Other } \\
\text { Shelters } \\
(n=41)\end{array}$} & \multirow{2}{*}{$\begin{array}{c}\begin{array}{c}\text { Significance } \\
\text { Level }\end{array} \\
\qquad p<.00\end{array}$} \\
\hline & & $\begin{array}{l}90.5 \\
18.7\end{array}$ & & $\begin{array}{l}34.4 \\
31.9\end{array}$ & \\
\hline $\begin{array}{l}\text { Eviction due to } \\
\text { inability to pay rent }\end{array}$ & $\begin{array}{l}\mathrm{M} \\
\mathrm{SD}\end{array}$ & $\begin{array}{l}13.1 \\
20.5\end{array}$ & $\begin{array}{l}\mathrm{M} \\
\mathrm{SD}\end{array}$ & $\begin{array}{l}36.1 \\
28.6\end{array}$ & $\mathrm{p}=.02$ \\
\hline $\begin{array}{l}\text { Substance abuse of } \\
\text { other household member }\end{array}$ & $\begin{array}{l}M \\
\text { SD }\end{array}$ & $\begin{array}{l}33.1 \\
27.3\end{array}$ & $\begin{array}{l}M \\
\text { SD }\end{array}$ & $\begin{array}{l}26.7 \\
21.6\end{array}$ & $\mathrm{p}=.37$ \\
\hline $\begin{array}{l}\text { Asked to leave housing } \\
\text { provided by friends or relatives }\end{array}$ & $\begin{array}{l}M \\
\text { SD }\end{array}$ & $\begin{array}{l}17.6 \\
17.9\end{array}$ & $\begin{array}{l}\text { M } \\
\text { SD }\end{array}$ & $\begin{array}{l}31.7 \\
25.8\end{array}$ & $\mathrm{p}=.08$ \\
\hline Mother's substance abuse & $\begin{array}{l}M \\
\text { SD }\end{array}$ & $\begin{array}{l}18.5 \\
22.1\end{array}$ & $\begin{array}{l}M \\
\text { SD }\end{array}$ & $\begin{array}{l}30.5 \\
25.4\end{array}$ & $\mathrm{p}=.15$ \\
\hline $\begin{array}{l}\text { Disagreements with } \\
\text { family and friends }\end{array}$ & $\begin{array}{l}M \\
\text { SD }\end{array}$ & $\begin{array}{l}12.5 \\
18.9\end{array}$ & $\begin{array}{l}M \\
\text { SD }\end{array}$ & $\begin{array}{l}24.8 \\
23.8\end{array}$ & $\mathrm{p}=.24$ \\
\hline Job loss & $\begin{array}{l}\mathrm{M} \\
\mathrm{SD}\end{array}$ & $\begin{array}{l}15.1 \\
22.7\end{array}$ & $\begin{array}{l}M \\
\text { SD }\end{array}$ & $\begin{array}{l}17.4 \\
21.5\end{array}$ & $\mathrm{p}=.80$ \\
\hline $\begin{array}{l}\text { Unsafe conditions } \\
\text { in previous housing }\end{array}$ & $\begin{array}{l}\mathrm{M} \\
\mathrm{SD}\end{array}$ & $\begin{array}{l}5.3 \\
9.8\end{array}$ & $\begin{array}{l}\mathrm{M} \\
\mathrm{SD}\end{array}$ & $\begin{array}{l}17.4 \\
22.9\end{array}$ & $\mathrm{p}=.31$ \\
\hline Mother's mental illness & $\begin{array}{l}M \\
\text { SD }\end{array}$ & $\begin{array}{l}9.2 \\
8.7\end{array}$ & $\begin{array}{l}\mathrm{M} \\
\mathrm{SD}\end{array}$ & $\begin{array}{l}7.9 \\
7.4\end{array}$ & $p=.65$ \\
\hline
\end{tabular}

Hotelling's test of significance $=.65 ; \mathrm{F}=.31$ 
Table 2. Proportion of homeless mothers in participating shelters who experience specific problems.

\begin{tabular}{|c|c|c|c|c|c|c|}
\hline Problem & $<10 \%$ & $10-24 \%$ & $25-49 \%$ & $50-75 \%$ & $75-90 \%$ & $>90 \%$ \\
\hline $\begin{array}{l}\text { Mental illness other } \\
\text { than depression }\end{array}$ & 47.6 & 23.8 & 19.0 & 8.3 & 0 & 1.2 \\
\hline Depression & 4.7 & 24.4 & 26.7 & 19.8 & 12.8 & 11.6 \\
\hline Substance abuse & 11.8 & 22.4 & 28.2 & 24.7 & 10.6 & 2.4 \\
\hline Physical illness & 27.7 & 43.4 & 15.7 & 9.6 & 2.4 & 1.2 \\
\hline $\begin{array}{l}\text { Relationship with } \\
\text { substance abuser }\end{array}$ & 2.3 & 12.8 & 14.0 & 31.4 & 30.2 & 9.3 \\
\hline Abusive relationships & 3.4 & 8.0 & 12.6 & 10.3 & 11.5 & 54.0 \\
\hline Sexual assault & 20.7 & 23.2 & 14.6 & 18.3 & 19.5 & 3.7 \\
\hline Poor job skills & 0 & 7.1 & 19.0 & 39.3 & 26.2 & 8.3 \\
\hline Did not finish high school & 14.7 & 9.4 & 34.1 & 30.6 & 16.5 & 4.7 \\
\hline $\begin{array}{l}\text { Could not find } \\
\text { affordable housing }\end{array}$ & 7.1 & 11.8 & 9.4 & 14.1 & 34.1 & 23.5 \\
\hline Unwilling to work & 30.6 & 27.1 & 21.2 & 11.8 & 5.9 & 3.5 \\
\hline $\begin{array}{l}\text { Willing to work, } \\
\text { but can't find job }\end{array}$ & 17.4 & 26.7 & 26.7 & 15.1 & 11.6 & 2.3 \\
\hline $\begin{array}{l}\text { Potential wages } \\
\text { would not adequately } \\
\text { provide for family }\end{array}$ & 2.3 & 5.7 & 11.5 & 25.3 & 44.8 & 10.3 \\
\hline $\begin{array}{l}\text { Working, but not earning } \\
\text { enough to meet needs }\end{array}$ & 3.4 & 21.8 & 17.2 & 21.8 & 26.4 & 9.2 \\
\hline Lack of social supports & 10.3 & 17.2 & 18.4 & 27.6 & 18.4 & 8.0 \\
\hline
\end{tabular}

inability to earn adequate wages to support their families, poor job skills, lack of a high school education, and inability to find affordable housing. Interestingly, $57.4 \%$ of service providers reported that at least half of the mothers in their shelters were working but were not making enough to meet family needs. Another frequently mentioned problem was that many of these women have an ongoing relationship with a substance abuser.

$T$-tests were run to determine differences in responses according to shelter type or the educational background of the respondent. The only significant difference was that respondents from domestic violence shelters were more likely than re- spondents from other shelters to perceive mothers' abusive relationships as a problem. Again, Hotelling's test indicates that this finding could be due to chance (Hotelling's $=.18 ; \mathrm{F}=.82$ ), but it is more likely that it is an actual difference in that most women enter domestic violence shelters as a result of abuse. No difference in perceptions of problems between respondents who did and did not have social work degrees was found.

Service providers reported relatively few psychiatric problems other than depression among these mothers, but $56 \%$ reported that up to half of the mothers they serve do suffer from depression. This figure is actually a bit lower than findings from other studies that have reported depression rates of $59 \%$ to $68 \%$ among homeless women (Burt \& Cohen, 1989; Goodman, 1991). However, it is important to keep in mind that the data in this study are based on service providers' perceptions, whereas Burt and Cohen and Goodman utilized psychological measures. Two thirds of the respondents reported that fewer than half of the mothers in their shelters have a substance-abuse problem. Contrary to popular stereotypes about poor mothers, these service providers do not see unwillingness to work as a major problem.

Respondents were asked to indicate how important they believed certain factors were to families' ability to obtain and keep adequate housing. Table 3 presents ranked mean scores for each factor. No significant differences were found in the mean scores according to shelter type or educational background of the respondents on any of the factors. The small variation among the mean responses indicates that, in general, respondents did not see any factors as being significantly more important than others. However, they did rank mothers' attitude and motivation as most important and access to financial and other services (even access to housing) as less important. The lack of importance attributed to access to mental health or substance-abuse treatment probably reflects relatively lower rates of substance abuse and psychiatric problems among homeless mothers than among other homeless people with whom service providers would have contact. The low ranking of social support is somewhat surprising in light of findings from the Stanford study 
Table 3. Importance of factors in successful restabilization.

\begin{tabular}{lcc}
\hline Factor & $\begin{array}{c}\text { Mean } \\
(N=88)\end{array}$ & SD \\
\hline Attitude/motivation & 3.5 & .43 \\
$\begin{array}{l}\text { Financial and } \\
\text { food assistance }\end{array}$ & 3.4 & .67 \\
$\begin{array}{l}\text { Employment } \\
\text { opportunities }\end{array}$ & 3.3 & .73 \\
Housing & 3.2 & .58 \\
Coping skills & 3.1 & .57 \\
Education/training & 3.0 & .91 \\
Access to MH/SA & 2.6 & .90 \\
treatment & & \\
Social support & 2.5 & .47 \\
\hline
\end{tabular}

Scale: 1 = not important; 2 = somewhat important; 3 = important; 4 = very important

(1991) that social support from family and friends is a major factor in emerging from homelessness. However, the perceptions of service providers in the current study may reflect the fact that many homeless families do not have support systems that provide more than minimal assistance (Shinn, Knickman, \& Weitzman, 1991).

Table 4 presents respondents' perceptions regarding the importance of particular factors in contributing to difficulties families face in their effort to be successfully restabilized. Again, little variation among mean responses was found. However, certain factors appear to be somewhat less problematic than others. Access to financial and food assistance and to education and training opportunities were not perceived as serious barriers to family restabilization, probably because of the availability of AFDC and food stamps and access to job-training programs through the welfare system (e.g., the former JOBS program). The prominence of relation- ship difficulties and social supports in this ranking again probably reflects the limitations of poor families' social networks, the many families leaving abusive relationships, and ongoing relationships between mothers and substance abusers. No difference was found in means according to educational background of the respondent. However, respondents from domestic violence shelters were more likely than respondents from other shelters to view relationship difficulties as a problem in restabilization efforts. The Hotelling's statistic indicates that this finding was due to chance, although practically and theoretically this difference makes sense.

Table 5 presents findings related to respondents' perceptions of the service structure in their communities as helping or hindering families' attempts to emerge from homelessness. In general, limited housing opportunities were seen to be the most significant barrier to families seeking a new home; no aspect of the community service structure was considered to be a major asset. Even financial assistance and concrete service provision were perceived to be somewhat neutral in their effect on families' attempts to emerge from homelessness. No difference in mean responses according to shelter type was found. However, social workers were significantly more likely than non-social workers to perceive that local housing, financial and concrete services, and employment and training op-

\begin{tabular}{|c|c|c|c|c|c|}
\hline \multirow{2}{*}{$\frac{\text { Factor }}{\text { Relationship problems }}$} & \multicolumn{2}{|c|}{$\begin{array}{l}\text { Domestic } \\
\text { Violence } \\
(\mathrm{n}=47)\end{array}$} & \multicolumn{2}{|c|}{$\begin{array}{l}\text { All Other } \\
\text { Shelters } \\
(\mathrm{n}=41)\end{array}$} & \multirow{2}{*}{$\frac{\begin{array}{c}\text { Significance } \\
\text { Level }\end{array}}{p<.00}$} \\
\hline & $\begin{array}{l}\text { M } \\
\text { SD }\end{array}$ & $\begin{array}{l}3.7 \\
.49\end{array}$ & $\begin{array}{l}M \\
\text { SD }\end{array}$ & $\begin{array}{r}3.22 \\
.79\end{array}$ & \\
\hline Lack of social supports & $\begin{array}{l}\mathrm{M} \\
\mathrm{SD}\end{array}$ & $\begin{array}{l}3.2 \\
.74\end{array}$ & $\begin{array}{l}\text { M } \\
\text { SD }\end{array}$ & $\begin{array}{r}3.13 \\
.74\end{array}$ & $p=.73$ \\
\hline $\begin{array}{l}\text { Difficulty securing employment/ } \\
\text { poor skills }\end{array}$ & $\begin{array}{l}\mathrm{M} \\
\mathrm{SD}\end{array}$ & $\begin{array}{l}3.2 \\
.78\end{array}$ & $\begin{array}{l}M \\
\text { SD }\end{array}$ & $\begin{array}{l}3.1 \\
.72\end{array}$ & $p=.48$ \\
\hline $\begin{array}{l}\text { Poor attitude/motivation; } \\
\text { lack of commitment }\end{array}$ & $\begin{array}{l}\mathrm{M} \\
\mathrm{SD}\end{array}$ & $\begin{array}{l}3.1 \\
.72\end{array}$ & $\begin{array}{l}M \\
S D\end{array}$ & $\begin{array}{l}3.0 \\
.72\end{array}$ & $\mathrm{p}=.50$ \\
\hline $\begin{array}{l}\text { Lack of access to } \\
\text { housing assistance }\end{array}$ & $\begin{array}{l}\mathrm{M} \\
\mathrm{SD}\end{array}$ & $\begin{array}{l}3.1 \\
.89\end{array}$ & $\begin{array}{l}\mathrm{M} \\
\mathrm{SD}\end{array}$ & $\begin{array}{l}3.0 \\
.97\end{array}$ & $\mathrm{p}=.41$ \\
\hline Poor coping skills & $\begin{array}{l}\mathrm{M} \\
\mathrm{SD}\end{array}$ & $\begin{array}{l}2.8 \\
.64\end{array}$ & $\begin{array}{l}\mathrm{M} \\
\mathrm{SD}\end{array}$ & $\begin{array}{l}2.9 \\
.76\end{array}$ & $p=.66$ \\
\hline Substance abuse & $\begin{array}{l}\mathrm{M} \\
\mathrm{SD}\end{array}$ & $\begin{array}{l}2.9 \\
.98\end{array}$ & $\begin{array}{l}\mathrm{M} \\
\mathrm{SD}\end{array}$ & $\begin{array}{l}2.7 \\
.95\end{array}$ & $\mathrm{p}=.51$ \\
\hline $\begin{array}{l}\text { Lack of access to } \\
\text { MH/SA treatment }\end{array}$ & $\begin{array}{l}\mathrm{M} \\
\mathrm{SD}\end{array}$ & $\begin{array}{l}2.4 \\
.97\end{array}$ & $\begin{array}{l}M \\
\text { SD }\end{array}$ & $\begin{array}{l}2.6 \\
1.0\end{array}$ & $p=.49$ \\
\hline $\begin{array}{l}\text { Lack of access to } \\
\text { education/training }\end{array}$ & $\begin{array}{l}\mathrm{M} \\
\mathrm{SD}\end{array}$ & $\begin{array}{l}2.4 \\
.83\end{array}$ & $\begin{array}{l}M \\
\text { SD }\end{array}$ & $\begin{array}{l}2.4 \\
.97\end{array}$ & $p=.96$ \\
\hline $\begin{array}{l}\text { Poor access to financial } \\
\text { and food assistance }\end{array}$ & $\begin{array}{l}\mathrm{M} \\
\mathrm{SD}\end{array}$ & $\begin{array}{l}2.5 \\
1.0\end{array}$ & $\begin{array}{l}\mathrm{M} \\
\mathrm{SD}\end{array}$ & $\begin{array}{l}2.2 \\
1.1\end{array}$ & $p=.26$ \\
\hline
\end{tabular}

Scale: 1 = not important; 2 = somewhat important; 3 = important; 4 = very important Hotelling's test of significance $=.25 ; \mathrm{F}=.07$ 
Table 5. Perceptions of how local community services belp or hinder the process of restabilization by educational background of respondent.

\begin{tabular}{|c|c|c|c|c|c|}
\hline \multirow{2}{*}{$\begin{array}{l}\text { Service } \\
\text { Component } \\
\text { Financial and concrete services }\end{array}$} & \multicolumn{2}{|c|}{$\begin{array}{l}\text { Social Work } \\
\text { Degree } \\
(n=12)\end{array}$} & \multicolumn{2}{|c|}{$\begin{array}{l}\text { No Social } \\
\text { Work Degree } \\
(n=75)\end{array}$} & \multirow{2}{*}{$\begin{array}{c}\begin{array}{c}\text { Significance } \\
\text { Level }\end{array} \\
p=.004\end{array}$} \\
\hline & $\begin{array}{l}M \\
S D\end{array}$ & $\begin{array}{l}2.7 \\
.91\end{array}$ & $\begin{array}{l}M \\
S D\end{array}$ & $\begin{array}{l}3.4 \\
.71\end{array}$ & \\
\hline Employment/training opportunities & $\begin{array}{l}M \\
\text { SD }\end{array}$ & $\begin{array}{c}1.7 \\
.91\end{array}$ & $\begin{array}{l}\mathrm{M} \\
\mathrm{SD}\end{array}$ & $\begin{array}{r}2.2 \\
.75\end{array}$ & $\mathrm{p}=.02$ \\
\hline $\begin{array}{l}\text { Other community services } \\
\text { (access to health, mental health } \\
\text { and substance abuse treatment) }\end{array}$ & $\begin{array}{l}M \\
S D\end{array}$ & $\begin{array}{c}2.8 \\
.98\end{array}$ & $\begin{array}{l}M \\
S D\end{array}$ & $\begin{array}{l}2.8 \\
1.0\end{array}$ & $\mathrm{p}=.98$ \\
\hline Housing & $\begin{array}{l}\mathrm{M} \\
\mathrm{SD}\end{array}$ & $\begin{array}{l}1.5 \\
.20\end{array}$ & $\begin{array}{l}M \\
\text { SD }\end{array}$ & $\begin{array}{r}2.2 \\
.76\end{array}$ & $\mathrm{p}=.009$ \\
\hline
\end{tabular}

Scale: 1 = major barrier; 2 = somewhat a barrier; $3=$ neither an asset nor a barrier; $4=$ somewhat an asset; $5=$ major asset.

Hotelling's test of significance $=.21 ; \mathrm{F}=.004$

portunities were more serious barriers to the restabilization process. The small amount of variation in the responses between the two groups, however, raises a questions about the practical significance of this finding.

\section{Strengths and Limitations of the Study}

Because this study was exploratory and used a nonrandom sample, caution should be taken in generalizing the findings, especially those based on the results of the $t$ tests. However, certain characteristics of the sample support the validity of the findings. The service providers who responded to the survey had been working with homeless people for an average of 12 years and thus are drawing on a wealth of knowledge and experience. They also have worked at their current shelter for an average of five years and thus would be expected to have a good understanding of the populations they serve as well as of the local community and its resources. Furthermore, the information they provided about the homeless mother-headed families they serve corroborates findings from other studies (e.g., similar reasons for homelessness and types of problems).

Another limitation of the study is the small amount of variation among responses. For example, the largest difference in mean scores between top- and bottom-ranked items on Tables $2-4$ was only 1.2. Thus, it is difficult to say that service providers perceive very much difference among the factors related to success and difficulty in the restabilization process. Future research into the roles and relative contributions that various factors play in determining what families are able to successfully emerge from homelessness would help clarify these issues.

Finally, one characteristic of the study is both a limitation and an asset. Because the respondents come primarily from counties with populations less than 200,000 , care should be exercised in generalizing the findings to large urban areas. However, the demographic makeup of this study provides a contribution to the body of knowledge about homelessness outside metropolitan areas, where most studies of homelessness have been conducted. In addition, future research should be done to determine whether service providers in other areas of the country outside the South share similar perceptions about factors that affect the process of restabilization, focusing specifically on the relative contribution of individual and systemic factors.

\section{Discussion and Implications}

Even given the limitations of this study, it is important to note that, in general, service providers who responded to this survey seemed to place more importance on individual factors associated with the process of restabilization than on structural or systemic factors. This perception is in conflict with the finding of the Stanford study (1991) that personal characteristics were actually less crucial to getting out of homelessness than were social and systemic factors. It is possible that two differences between the samples could account for this discrepancy. First, the two studies differed in terms of demographics: the counties represented in the Stanford study were much more urban than those in the present study and thus may have a wider and more accessible range of services for homeless families. Second, the two studies focused on different types of homeless families: the present study focused on 
homeless mother-headed families only, whereas the Stanford study included two-parent and fatherheaded families.

A more plausible interpretation is that these two findings do not, in fact, contradict each other, but rather support the position asserted by many researchers and homeless advocates that homelessness is a result of both systemic and individual factors. In the absence of an adequate low-income housing stock (a systemic factor), homelessness has been likened to a game of musical chairs (McChesney, 1990), with individual factors such as attitude, motivation, mental health, persistence, and so forth playing a major role in determining who is able to secure housing.

In the present study, service providers ranked systemic factors such as availability of financial assistance, food, and other concrete services highest among ways in which communities help the process of restabilization. Lack of access to such assistance was ranked lowest among factors that contribute to families' difficulties. Thus, service providers seem to think that families are getting their basic needs, other than housing, met through community resources. Although respondents acknowledged that adequate housing was not readily available, they nevertheless did not rank lack of housing assistance high on the list of factors that make it difficult for families to emerge from homelessness. This ranking is in contrast with that of service providers and families in the Stanford study (1991), who rated this factor very highly. The high ranking that service providers attributed to motivation and attitude, as shown in Table 3, seems to indicate a tendency to hold mothers personally responsible for not being able to secure housing, even though service providers acknowledge the lack of available housing in their communities.

\section{$6 \mathrm{On}_{\text {ne of the most surprising }}$} findings is that social work training seems to have little effect on service providers" perceptions with regard to success and difficultr factors."

The possibility that service providers may discount the effect of systemic factors on families' ability to emerge from homelessness is disturbing, particularly in light of research on how service providers' perceptions of client responsibility influence the services that clients receive. Degarmo and colleagues (1993) found that clients "who were seen as personally responsible for their circumstances were considered undeserving of assistance, while those who were victims of forces beyond their control ... qualified as deserving clients of available social services" (p. 69). In agencies where service providers had the discretion to make decisions regarding clients' eligibility for services, workers were most likely to rely on their perceptions of client responsibility in determining how or if clients would be helped. Thus, if service providers perceive some homeless mothers as less motivated or as having a "bad attitude," they may be less likely to extend necessary help.

Another important finding is that little difference was found between the restabilization process for homeless families that are leaving abusive relationships and those that are homeless for other reasons, other than the fact that the mother must deal with the effects of having been in and left such a relationship. Respondents' perceptions of success factors did not differ by shelter type, and the only difference noted on the Difficulties scale related to relationship problems. Thus, the service providers who responded to this study support Browne's (1993) contention that homeless women who have survived abuse must overcome the same barriers as other homeless women, with the added burden of dealing with the psychological and emotional effects of abuse.

It is possible that the lack of motivation and "bad attitude" noted by respondents in this study could be attributable to the widespread depression experienced by homeless mothers (Bassuk, 1990; Bassuk \& Rosenberg, 1988) or to PTSD (Browne, 1993; Goodman et al., 1991). How would service providers interact differently with mothers if they perceived their difficulties with motivation, commitment, and attitude as resulting from depression or PTSD rather than from personal deficits? Although the service providers who responded to this study indicated that a large percentage of the women they serve do suffer from depression, this study did not explore how that knowledge affects how providers work with the women. Many service providers 
may not be fully aware of the high rates of depression and PTSD among homeless women or understand the devastating impact depression or PTSD can have on one's energy level and ability to carry out even simple tasks. Does this lack of understanding sometimes result in service providers "blaming the victim" (Ryan, 1976) and thus being less than effective in helping families become restabilized?

One of the most surprising findings is that social work training seems to have little effect on service providers' perceptions with regard to success and difficulty factors. Social workers were no less likely to attribute successful restabilization to clients' attitude or motivation than were respondents who were not social workers. Similarly, no difference was found according to educational background on respondents' perceptions about why families have difficulty emerging from homelessness. One might have expected social workers to be more likely to recognize the importance of systemic factors that contribute to family homelessness and make restabilization difficult because the ecological perspective is taught in most social work education programs and because social workers are trained to recognize macro- as well as micro- level factors in working with clients and understanding social problems. Social workers were somewhat more likely than were respondents without social work training to perceive that elements of the service structure in their communities hindered rather than helped the restabilization process. However, the differences between the two groups were minimal and are of questionable practical significance. Thus, it appears that social workers, as well as those with other educational backgrounds, need special preparation and training to work effectively with this population.

Training is needed to assure that service providers to homeless families fully understand the interplay of systemic, social, and personal factors that lead to homelessness. Such training would minimize the likelihood that clients are held

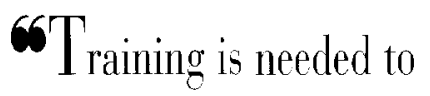
assure that service providers to homeless families fully understand the interplay of svstemic, social, and personal factors that lead to homelessness."

individually responsible for what has become a national systemic problem. Furthermore, service providers need to learn techniques for motivating clients and for helping clients sustain that motivation in the face of adversity. They also need to be able to recognize when symptoms of depression, PTSD, or other emotional disturbance are severe enough to warrant referral to mental health services. Not all battered women enter domestic violence shelters because of the shortage of space; thus it is important that staff in other shelters that serve families be trained to recognize the psychological and emo- tional symptoms of battering so that effective referrals can be made.

This study is relevant to the current social service climate created by welfare reform initiatives. In 1994, when this study was conducted, service providers perceived that financial assistance and other concrete services were very important elements in families' ability to emerge successfully from homelessness. This finding echoed mothers' perceptions that without public assistance they did not know how they would have been able to care for their children while they attempted to restabilize their life situation (Lindsey, 1996). At that time, AFDC and food stamps were entitlements that were readily available to poor families. With passage of the Personal Responsibility and Work Opportunity Act of 1996, financial assistance to poor families will no longer be guaranteed. Many homeless advocates and researchers have predicted that the passage of this legislation will lead to increased homelessness. The importance that service providers who responded to this survey place on the availability of this type of assistance supports that argument. For this dire prediction not to become a reality, communities must overcome their reluctance to deal with this issue (Dluhy, 1990) and begin to address such structural issues as lack of affordable housing, the need for affordable day care for working parents, creation of jobs that pay a living wage for families, and more effective education and job-training programs. Service providers who understand the interplay of systemic, social, and personal factors in homelessness need to take 
the lead in influencing welfare and housing policies and in addressing structural service provision as well as in helping families resolve personal and social issues that contribute to their plight.

\section{Conclusion}

Homelessness and lack of affordable housing are not problems only in large metropolitan areas. Such problems have moved into smaller communities such as the ones represented in this study. Service providers' perceptions of the ways in which personal, social, and systemic factors influence the process by which families are able to emerge from homelessness indicate that a range of coordinated efforts at various system levels is necessary to solve, manage, and prevent family homelessness. At the level of direct-service provision, service providers themselves must be educated on the multifaceted causes of homelessness, including domestic violence, and on how to work effectively with mothers who are experiencing the psychological trauma of homelessness and other disruptive life events, including abuse. Training should help service providers understand how their own perceptions of the causes of homelessness can negatively influence their attitudes toward clients and their ability to provide needed services. At the community level, with welfare reform and declining federal commitment to housing programs, local communities must assume responsibility for developing strategies to prevent homelessness and for helping families who do become homeless become stabilized as soon as possible. Future research efforts should attempt to identify the relative contributions of various factors that lead to homelessness and the processes by which families are able to emerge from homelessness. Such knowledge would provide information that advocates can use to support calls for more humane and effective social policies and programs designed to prevent and ameliorate family homelessness.

\section{References}

Bassuk, E. L. (1990). Who are the homeless families? Characteristics of shelter mothers and children. Community Mental Health Joumal, 26, 425-433.

Bassuk, E. L., \& Rosenberg, L. (1988). Why does family homelessness occur? A case-control study. American Journal of Public Health, 78, 783-788.

Browne, A. (1993). Family violence and homelessness: The relevance of trauma histories in the lives of homeless women. American Journal of $\mathrm{Or}$ thopsychiatry, 63, 370-384.

Burt, M. R., \& Cohen, B. F. (1989). Differences among homeless single women, women with children, and single men. Social Problems, 36, 508-524.

Degarmo, D. S., Feltey, K. M., \& Pendleton, B. F. (1993). Models of responsibility and helping the homeless: Perceptions of service providers and their role. Journal of Applied Sociology, 10, 49-63.

Dillman, D. A. (1978). Mail and telephone surveys: The total design method. New York: John Wiley.

Dluhy, M. J. (1990). Community perceptions of the homeless: Factors in intervention strategies with the homeless. Social Work, 26, 18-24.

Goodman, L. (1991). The prevalence of abuse among homeless and housed poor mothers: A comparison study. American Journal of Orthopsychiatry, 61, 489-500.

Goodman, L., Saxe, L., \& Harvey, M. (1991). Homelessness as psychological trauma: Broadening perspectives. American Psychologist, 46,
1219-1225.

Hagen, J. L., \& Hutchison, E. (1988). Who's serving the homeless? Social Casework, 69, 491-497.

Hall, J. A., \& Maza, P. L. (1990). No fixed address: The effects of homelessness on families and children. Child and Youth Services, 14, 35-47.

Hutchison, W. J., Searight, P., \& Stretch, J. J. (1986). Multidimensional networking. A response to the needs of homeless families. Social Work, 31, $427-430$.

Johnson, A. K. (1989). Female-headed homeless families: A comparative profile. Affilia, 4(4), 23-39.

Lindsey, E. W. (1994-95). Creating a new home: The process by which motherheaded homeless families become stably rehoused. Doctoral diss., University of Georgia. Dissertation Abstracts International, 53(9), 3009-A.

Lindsey, E. W. (1996). Mothers' perceptions of factors influencing the process of restabilization among bomeless families. Families in Society, 77, 203-215.

McChesney, K. Y. (1990). Family homelessness. A systemic problem. Journal of Social Issues, 46, 191-205.

Mills, C., \& Ota, H. (1989). Homeless women with minor children in the Detroit metropolitan area. Social Work, $34,485-489$.

National Coalition for the Homeless. (1996). Domestic violence and bomelessness (NCH Fact Sheet). http:/nch.ari.net/domestic.html.

Phillips, M. H., DeChillo, N., Kronenfeld, D., \& Middleton- Jeter, V. (1988). Homeless families: Services make a difference. Social Casework, 69, 48-53.

Rafferty, Y., \& Shinn, M. (1991). The impact of homelessness on children. American Psychologist, 46, 1170-1179.

Reyes, L. M., \& Waxman, L. D. (1986). The continued growth of bunger, homelessness, and poverty in America's cities: 1986. Washington, DC: U.S. Conference of Mayors.

Reyes, L. M., \& Waxman, L. D. (1989a). A status report on bunger and homelessness in America's cities: 1988. Washington, DC: U.S. Conference of Mayors.

Reyes, L. M., \& Waxman, L. D. (1989b). A status report on bunger and homelessness in America's cities, 1989: A 27. city survey. Washington, DC: U.S. 
Conference of Mayors.

Rocha, C., Johnson, A. K., McChesney, K. Y., \& Butterfield, W. H. (1996). Predictors of permanent housing for sheltered homeless families. Families in Society, 77, 50-57.

Ryan, W. (1976). Blaming the victim. New York: Vintage Books.

Shinn, M., Knickman, J. R., \& Weitzman, B. C. (1991a). Social relationships and vulnerability to becoming homeless among poor families. American Psychologist, 46, 1180-1187.

The Stanford Center for the Study of Families, Children and Youth (1991). The Stanford studies of homeless families, children and youth. Stanford, CA.

Steinbock, M. R. (1995). Homeless femaleheaded families: Relationships at risk. Marriage and Family Review, 20(1-2), 143-159.

Tracy, E., \& Stoecker, R. (1993). Homelessness: The service providers' perspective on blaming the victim. Journal of Sociology or Social Welfare 20(3), 43-59.

U.S. Department of Housing and Urban Development. (1994). Priority: Home! The federal plan to break the cycle of homelessness. Washington, DC: Author.

Waxman, L., \& Hinderliter, S. (1996). A status report on bunger and bomeless in America's cities: 1996. Washington, DC: U.S. Conference of Mayors.

Weitzman, B. C., Knickman, J. R., \& Shinn, M. (1990). Pathways to homelessness among New York City families. Journal of Social Issues, 46(4), $125-140$.

Wright, J. D. (1990). Homelessness is not healthy for children and other living things. Child and Youth Services, $14(1), 65-88$

Zorza, J. (1991). Woman battering. A major cause of homelessness. Clearinghouse Review, 25, 421-429. 